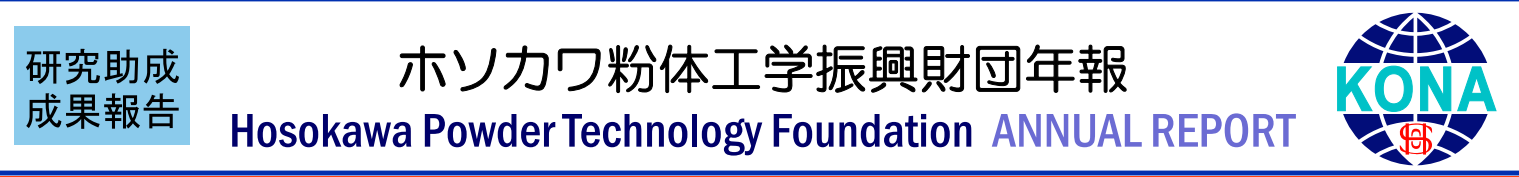

17105

\title{
水系メカノケミカル重合によるシリカフィラーの調製 \\ Preparation of the Silica Filler by Mechanochemical Polymerization in Water
}

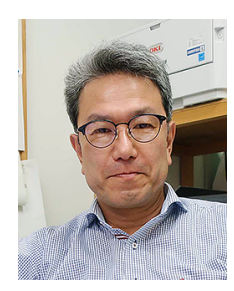

研究代表者 Research leader：木俣 光正 Mitsumasa KIMATA

山形大学大学院理工学研究科 教授

Graduate School of Science and Engineering, YamagataUniversity, Professor

E-mail: kimata@yz.yamagata-u.ac.jp

\section{抄 録}

メカノケミカル重合法は, 粉砕操作により生じる粉体破断面の活性点を利用した重合反応であり, 粉砕された無機表面をほぼ完全にポリマー被覆できる方法である。そこで, 現在リサイクル達成率 の低い自動車の廃ガラスに着目し，これをメカノケミカル重合処理により，シリカフィラーとして 再利用することを考えた。我々は最近, 遊星ミルのような粉砕能力の高い粉砕機でメカノケミカル 重合反応を行うことにより，水溶媒中に掞いてポリマーが生成することを見出した，そこで，水溶 媒を用いた湿式粉砕によるポリマー被覆シリカフィラーの調製について検討した。 その結果, 廃ガ ラスの表面をポリマーでコーティングされたシリカフィラーの調製に成功した。 したがって, 水溶 媒中に扔いて廃ガラスの粉砕により, メカノケミカル重合反応の進行が確認された。 また，原料の 粒子径によらず，生成物の粒子径はほぼ $200 \mathrm{~nm}$ 程度であった。

\begin{abstract}
The mechanochemical polymerization method uses active center of the powder fracture surface to produce by grinding operation, and it is method to approximately completely carry out a polymer coating in crushed inorganic surface. We focused the attention on the waste glass of the car which had low recycling percentage achievement, and we thought about reusing this as silica filler by mechanochemical polymerization processing now. We found what a polymer generated in the water recently by carrying out mechanochemical polymerization reaction with the high ability mill for grinding such as the planetary mill. Therefore, a preparation of the polymer coating silica filler by the wet grinding using the water was investigated. As a result, we succeeded in a preparation of the silica filler that surface of the waste glass was coated with a polymer. Hence progress of the mechanochemical polymerization reaction was confirmed by grinding of the waste glass in the water. In addition, the particle diameter of the product was around $200 \mathrm{~nm}$ without depending on the particle diameter of raw materials.
\end{abstract}




\section{研究背景と目的}

単一素材では性能の限界があるものも，他の 材料と組み合わせた複合材料とすることで，高 機能化やさらに新しい機能を付加することが可 能となる，特に無機フィラーはポリマーマト リックス中に分散させることで難燃性や高熱伝 導性など様々な機能を発現させることができ る。この際，無機フィラーにはポリマーとの親 和性向上のためカップリング剤により表面処理 されることが多い. 表面処理法には様々な化学 的反応プロセスがある中，機械的エネルギーを 加えることでポリマーコーティング可能なメカ ノケミカル重合法がある.メカノケミカル法は, 粉砕などの機械的操作によって複合材料を得る 方法であるため, 他の合成法に比べて操作や手 順が単純であることが利点として挙げられる。 また，表面処理と同時に試料の微細化を行うこ とができるため, 微粒子化のプロセスの短縮が 期待できる.

本研究室では, これまでメカノケミカル重合 反応に関する研究について振動ボールミルを用 い，粉砕によって生じるラジカルやイオンなど の活性点の失活を防ぐため, モノマー単独また は，n-ヘプタンやヘキサンのような非極性有 機溶媒を使用して, 不活性窒素䨌囲気下で重合 実験を行っていた（Hasegawa M. et al., 1997; 2002）（Kimata M. et al., 2013）。しかし，より粉 砕性の高い遊星ボールミルを用い, 水中でアル ミナと MMAのメカノケミカル重合反応を行っ た際，ラジカルを失活させると思われた水溶媒 下で重合反応の進行が確認された（Kimata M. and Chigira T., 2017).

一方, 年間 400 万台の廃車が発生している中 で, 自動車の廃ガラスはリサイクル達成率の最 も低い材料の一つである。 そこで本研究では, 自動車の廃ガラスをシリカフィラーとして有効 利用させるため, 廃ガラスを遊星ボールミルに より粉砕することにより, MMA との水系のメ カノケミカル重合反応を試みた，廃ガラスを粉 砕することにより，微細化とともに表面がポリ
マーコーティングされたシリカフィラーの調製 が期待できる。 また，水を溶媒として用いるこ とができれば，自然環境に与える負荷を軽減す ることができるほか, 溶媒のコストダウンにも つながると考えられる。 また，溶媒が水であれ ば振動ミルや遊星ミルのような密閉式の粉砕機 だけでなく, 大量生産に向いているビーズミル （Kimata M. et al., 2014）などの連続式の湿式粉 砕機への応用が期待できる。

\section{研 究 方 法}

\section{1. 実験試料および粉砕装置}

廃ガラスは, 粒子径 1160 〜 $600 \mu \mathrm{m}$ 㧍よび $75 \mu \mathrm{m}$ 以下に調製した普通自動車のサイドガラ ス(ソーダ石灰ガラス)を使用した. 試料は, (株) 山形県自動車販売店リサイクルセンターより, ガラス瓶専用破砕機（(株）カネ卜製作所製, びん丸戦士シリーズ）により約 $5 \mathrm{~mm}$ 角に粗砕 されたものが供給された。これをスタンプミル （日陶科学（株）製，ANS-143 型）にて 10 分 間粉砕し，ふるい目開き $1180 \mu \mathrm{m}, 600 \mu \mathrm{m}$, $75 \mu \mathrm{m}$ の JIS 試験用ふるいを用いて，ロータッ プシェイカーによって10 分間ふるい分けを行 い, 目開き $600 \mu \mathrm{m}$ のふるい上および $75 \mu \mathrm{m}$ の ふるい下に残ったものを実験に用いた。モと マーとして用いたメタクリル酸メチル（MMA） は, 市販試薬 (三菱レイヨン製) を窒素雲囲気 下，減圧蒸留して精製したものを使用した。ま た, 溶媒として用いた水は, 超純水製造装置（野 村マイクロサイエンス (株) 製, ミニピュア TW-300RU）から採取された純水を $100^{\circ} \mathrm{C} ， 30$ 分間窒素バブリングすることで溶存酸素を脱離 させた脱酸素水を用いた。

粉砕機は自転と公転の比が 2:1の遊星ボー ルミル（Retsch 製, PM100）を用い, 粉砕容器 はジルコニア製で内容積 $125 \mathrm{~cm}^{3}$ のものを，粉 砕媒体は直径 $5 \mathrm{~mm}$ のイットリア安定化ジルコ ニアビーズをそれぞれ用いた。 


\section{2. 実験方法}

実験は, 粉砕容器へ粉砕媒体, スラリー（廃 ガラス，モノマー，溶媒）の充填率を，それぞ れボール充填率 $J=0.5$, スラリー充填率 $U=1.0$ とし，これを一定として行った。また，ボール 充填率 $J$ とスラリー充填率 $U$ はそれぞれ以下 の式によって定義した。

$$
\begin{gathered}
J=\frac{\text { 充填したボールの見かけ体積 }\left[\mathrm{m}^{3}\right]}{\text { 粉砕容器の容積 }\left[\mathrm{m}^{3}\right]} \\
U=\frac{\text { 充填したスラリーの体積 }\left[\mathrm{m}^{3}\right]}{\text { 充填したボールの空隙体積 }\left[\mathrm{m}^{3}\right]}
\end{gathered}
$$

まず，乾燥窒素䨌囲気下のグローブバッグ内 にて, 粉砕容器に粉砕媒体, 廃ガラス, MMA, 脱酸素水を所定量入れ, 専用の治具で密閉した。 なお，廃ガラス， MMA，脱酸素水の体積比は， $1: 1: 8$ である。粉砕容器を遊星ミル内に取り 付け, 公転回転数 $400 \mathrm{rpm}, 0.5 \sim 9 \mathrm{~h}$ 粉砕を行っ た。な扮，この粉砕は所定時間まで容器を密閉 させて行う完全バッチ方式で行った. 粉砕後は, 多量の純水を加えながら生成物と媒体を分離, 洗浄した。 得られたスラリーは真空凍結乾燥機 により乾燥させ生成物を得た。

\section{3. 分析方法}

得られた生成物に対して, 生成ポリマー量お よび比表面積の測定, 表面およびポリマーコー ティング状態の観察を行った，次に，生成物に 対してソックスレー抽出を行い, 生成ポリマー を抽出し，ポリマーの同定を行った。具体的な 方法を以下に示した。

ポリマー量は差動型示差熱天秤（理学電機 （株）製，TG-DTA TG8210）を用いて，窒素雲 囲気下，昇温速度 $5^{\circ} \mathrm{C} / \mathrm{min}$ で $200 \sim 600^{\circ} \mathrm{C}$ の範 囲の減少率から求め, ポリマーへの転化率を計 算した。

複合物の表面状態の観察は, 走査型電子顕微 鏡/走査透過電子顕微鏡（(株）日立製，FESEM/STEM SU8000）を用いて行うとともに,
同視野サンプルについて，STEMによりポリ マーのコーティング状態について観察を行っ た。

比表面積測定は，流動式比表面積自動測定装 置（Quantachrome製，Monosorb ms-21）を用い た BET 1 点法により測定した。なお，測定試 料は，真空炉（フルテック（株）製，FT-101） を用いて，真空下， $200^{\circ} \mathrm{C}$ で 3 時間熱処理を行 うことで，複合物中のポリマーを取り除いたも のを使用した。

生成ポリマーの同定にはフーリエ変換赤外分 光光度計（HORIBA 製，FT-IR FT-720）を用い, $\mathrm{KBr}$ 錠剂法によって行った

ポリマーの分子量は, ゲル浸透クロマトグラ フィー（東ソー（株）製, GPC HLC-8220）に より，テトラヒドロフラン（THF）溶媒で測定 した。

\section{研 究成 果}

\section{1. 粉砕性とポリマー転化率}

図 1 に, 廃ガラスの粉砕によりメカノケミカ ル重合で生成したポリマーの転化率の経時変化 を示した，比較のため，石英を粉砕したときの

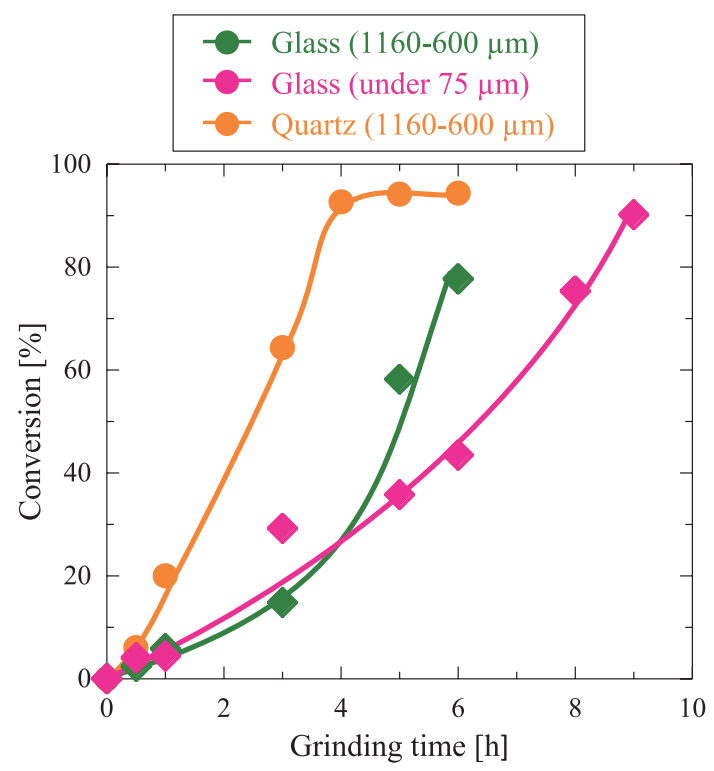

Fig. 1 Conversion of MMA as a function of grinding time. 
結果を併せて示した。図より, 非晶質の廃ガラ スを用いた粉砕においても粉砕時間の経過とと もに転化率の増加が見られ, メカノケミカル重 合反応の進行が確認された。転化率は粉砕初期 から緩やかな弧状に増加しており，ポリマーが 生成しない明確な誘導期は見られず，また，石 英よりも転化率の増加する時間が遅いことがわ かった，これは，ガラスが非晶質で塑性変形す ることから, 石英と比べて粉砕性が悪く, ラジ カルの生成量自体が少ないことが考えられる。 なお，廃ガラスは初期粒子径 1160-600 $\mu \mathrm{m}$ の方 が $75 \mu \mathrm{m}$ 以下のものよりポリマー生成速度が 大きいことがわかる。これは，初期粒子径の大 きい方が粉砕によって生成される新生表面が多 いため, 反応に寄与する活性点の生成量が多く なっていることが原因として考えられる。

図 2 に, 得られた生成物からポリマーを除去 後に測定した廃ガラスの比表面積の経時変化を 示した，比較のため，石英粒子を粉砕したとき の結果を併せて示した。 また, 粉砕性の比較の ため, 廃ガラスのみを脱酸素水中, 体積比 $1: 9$ で粉砕して得られた結果を白抜きのプロットで

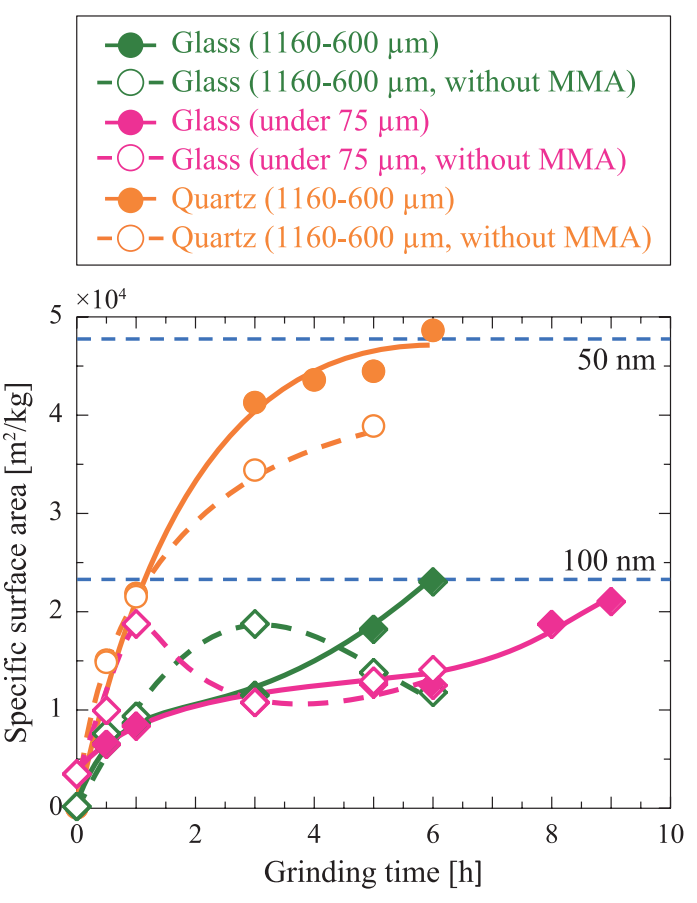

Fig. 2 Specific surface area as a function of grinding time.
示した。なお, 図中の破線は, 粉砕粒子を球状 と仮定して算出した比表面積径である。図より， 廃ガラスは石英と比べて粉砕後の比表面積が小 さいことがわかる. MMA 存在下でのガラスの 比表面積は粉砕時間とともになだらかに増加し ているのに対し，MMAを含まない条件では, 初期粒子径 1180-600 $\mu \mathrm{m}$ のものは 3 時間, 初期 粒子径 $75 \mu \mathrm{m}$ 以下のものでは 1 時間の粉砕で ピークに達したのち, 減少している。これはガ ラス粒子同士の凝集と塑性変形が原因と考えら れる。一方，MMA を含む場合は生成したポリ マーの影響のためか, 比表面積の増加はゆっく りであった。

比表面積はメカノラジカルの生成量と比例関 係にある（Hasegawa M. et al., 1993）ため, 廃 ガラスの比表面積と MMAのポリマー転化率と の関係を図 3 に示した。これまでと同様に比較 のため, 石英粒子を粉砕したときの結果を併せ て示した。図より, 廃ガラスは初期粒子径によ らず比表面積 $9 \times 10^{3} \mathrm{~m}^{2} / \mathrm{kg}$ 付近から急激に増 加していることが確認できる. 一方, 石英は比 表面積が廃ガラスの 3 倍程度あたりで転化率 の急激な増加が見られている。 これまでの研究 においては，石英ガラスは石英よりも大きな表 面積でメカノケミカル重合反応を生じており

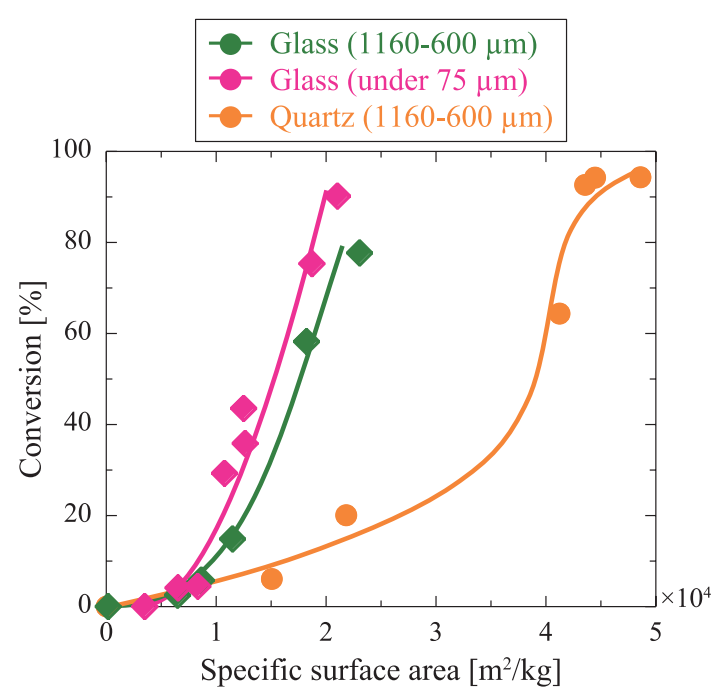

Fig. 3 Relationships between conversion of MMA and specific surface area. 
(Hasegawa M. et al., 1997), 今回の結果と異な る結果が得られた。これは，廃ガラスの粉砕性 の悪さが原因として考えられる。また，粉砕装 置の違いにより, より粉砕能力の高い遊星ボー ルミルにおいては，媒体による衝撃や剪断によ る廃ガラス表面の欠陥の増加が重合反応に影響 していると考えられるが, 詳細は不明である。

\section{2. 生成物表面の観察およびポリマーの同定}

困 4(a), (b) に初期粒子径の異なる廃ガラス を粉砕し, メカノケミカル重合反応によって得 られた生成物の SEM 画像および STEM 画像を それぞれ示した。なお, 各生成物の粉砕時間は, 1180-600 $\mu \mathrm{m}$ では 6 時間, $75 \mu \mathrm{m}$ 以下では 9 時 間のものをそれぞれ観察した。これらの SEM 画像から, 初期粉砕性の大きさにかかわらず, いずれの表面形状も滑らかになっており表面が ポリマーで被覆されている様子が観察できる。 SEM 画像と同視野の STEM 画像を見ると, 電 子線の透過率の違いから廃ガラスは黒く, その 周囲に半透明のポリマーの存在をはっきりと確 認することができる。廃ガラス粒子は，粉砕時 間は異なるものの比表面積はほとんど変わらな いため, 砕成物の大きさはほほ同じで約 $200 \mathrm{~nm}$ であった。

図 5 に各初期粒子径の廃ガラス粒子と MMA の粉砕により得られた生成物の FT-IR スペクト

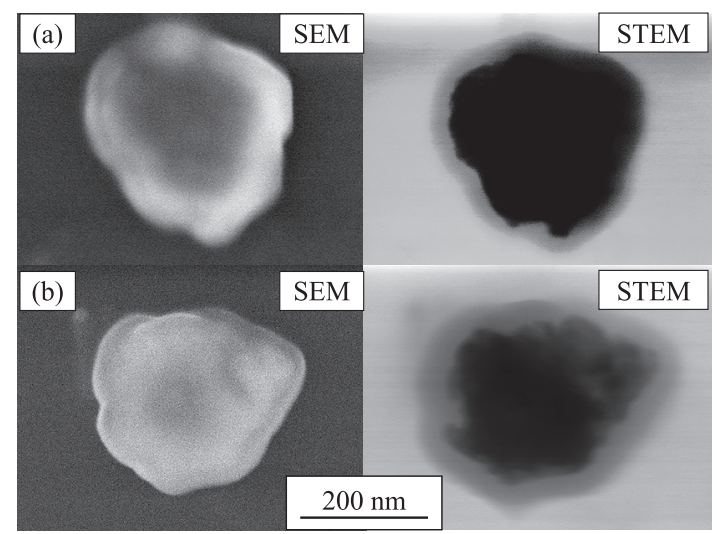

Fig. 4 SEM and STEM images of the products.

(a) $1180-600 \mu \mathrm{m}(5 \mathrm{~h})$, (b) Under $75 \mu \mathrm{m}$ (9 h) (Grinding time)
ルを示した，測定には，1160-600 $\mu \mathrm{m}$ のものは 6 時間, $75 \mu \mathrm{m}$ 以下のものでは 9 時間粉砕した ときの生成物について，それぞれソックスレー 抽出を 15 時間行うことで抽出したポリマーを 用いた。 また, メカノケミカル重合反応で得ら れたポリマーとの比較のために乳化重合によっ て得られた PMMAのFT-IR スペクトルを併せ て示した。図より, $1700 \mathrm{~cm}^{-1}$ 付近のカルボニ ル基の $\mathrm{C}=\mathrm{O}$ 結合の伸縮振動, $3000 \mathrm{~cm}^{-1}$ 付近の メチル基の C-H 結合の伸縮振動, 1150 $1500 \mathrm{~cm}^{-1}$ 付近のメチル基の C-H 結合の偏角振 動を示すピークが現れており, 乳化重合で得ら れたPMMA とピークの位置およびスペクトル の形状がほぼ一致していた。これらの結果から， 廃ガラスを用いたメカノケミカル重合反応に よって生成されたポリマーはPMMAであるこ とが確認された。

最後に各初期粒子径の廃ガラスを粉砕するこ とにより得られたポリマーの分子量を GPCに より測定した結果を示す。初期粒子径 1160$600 \mu \mathrm{m}$ を 6 時間粉砕して得られたポリマーの 数平均分子量 $\left(M_{\mathrm{n}}\right)$ は 31900 , 重量平均分子量 $\left(M_{\mathrm{w}}\right)$ は 97200 , 多分散度 $\left(M_{\mathrm{w}} / M_{\mathrm{n}}\right)$ は 3.05 , 初期粒子径 $75 \mu \mathrm{m}$ で 9 時間粉砕して得られた ポリマーの $M_{\mathrm{n}}$ は $41900, M_{\mathrm{w}}$ は $120000, M_{\mathrm{w}} / M_{\mathrm{n}}$

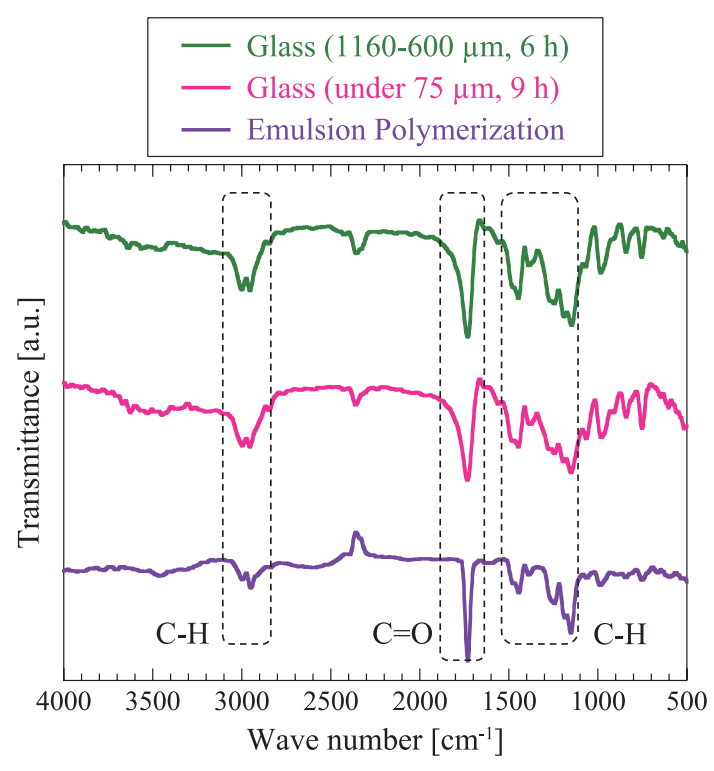

Fig. 5 FT-IR spectrum of the product polymers. 
は2.85であった，本実験によりメカノケミカ ル重合反応で得られたPMMAは数平均分子量 としては数万程度であり, 石英を粉砕して得ら れたものと大きく変わることはなかった。 しか し，多分散度は 3 程度と大きく，これは，粉砕 によるポリマーの切断が生じていることが原因 と考えられる。しかしながら， STEMからはポ リマー単独の粒子が見られることはないため, 多くは廃ガラスとともにポリマーがコーティン グされた状態で粉砕が進行しているものと思わ れる。

以上の結果, 廃ガラスを水溶媒中においてメ カノケミカル重合反応により $200 \mathrm{~nm}$ 程度のシ リカフィラーとすることに成功した。

\section{参考文献}

Hasegawa M., Kimata M., Kobayashi S., Mechanochemical copolymerization of methyl methacrylate and styrene initiated by the grinding of quartz, Journal of Applied Polymer Science, 84 (2002) 2011-2017. https://doi.org/10.1002/app.10544

\section{外部発表成果}

\section{口頭・ポスター発表}

1. 市村 凌一, 木俣 光正, “水溶媒中シリカの 粉砕によるMMAのメカノケミカル重合反
Hasegawa M., Ogata T., Sato M., Kanda Y., Mechanoradicals of quartz produced by grinding, Journal of the Society of Powder Technology, Japan, 30 (1993) 777-781. https://doi.org/10.4164/sptj.30.11_777

Hasegawa M., Sato M., Sakuyama S., Kimata M., The mechanochemical polymerization of methyl methacrylate initiated by the grinding of quartz and quartz glass, Journal of the Society of Powder Technology, Japan, 34 (1997) 10-16. https://doi.org/10.4164/sptj.34.10

Kimata M., Hasegawa M., Kotake N., Mechanochemical polymerization of methyl methacrylate initiated by the grinding of quartz in an n-heptane solvent, Powder Technology, 35 (2013) 336-340.

https://doi.org/10.1016/j.powtec.2012.10.027

Kimata M., Sato T., Hasegawa M, Mechanochemical polymerization of styrene by grinding of the minerals at bead mill, Journal of the Society of Powder Technology, Japan, 51 (2014) 424-429.

https://doi.org/10.4164/sptj.51.424

Kimata M., Chigira T., Effects of solvent on mechanochemical polymerization of methyl methacrylate initiated by grinding alumina, Journal of the Society of Powder Technology, Japan, 54 (2017) 776-781. https://doi.org/10.4164/sptj.54.776

応”, 化学工学会第 50 回秋季大会 (Kagoshima, Sept. 18-20, 2018） FE217.

2. 木俣光正, 市村凌一, 浅田凌汰, “シリカ の湿式粉砕によるMMAのメカノケミカル 重合反応”, 粉体工学会第 54 回技術討論会 （Nagoya, Sept. 3-4, 2019）一般-4. 